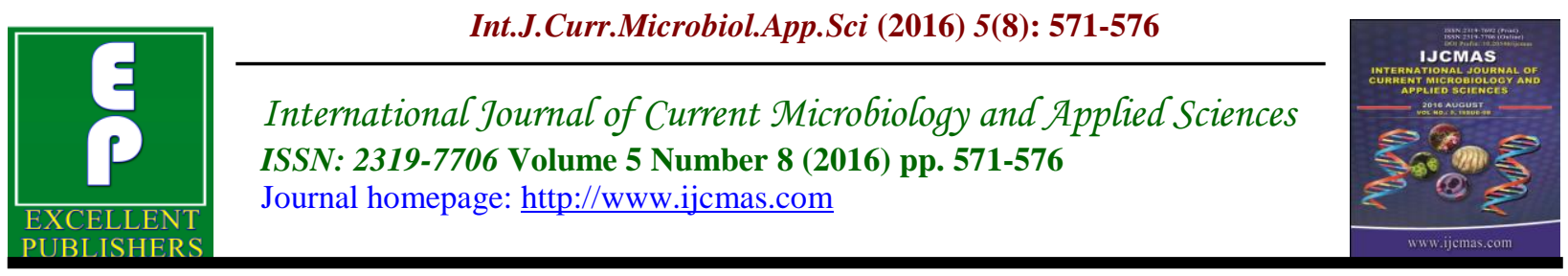

Original Research Article

http://dx.doi.org/10.20546/ijcmas.2016.508.063

\title{
Effect of Nutrients and Antioxidant Enzyme Activities from Microcystis aeruginosa
}

\author{
Yanfei Li, Ping Li, Peihang Xu, Yinglin Wu, Wenhua Liu* and C. Santhoshkumar* \\ Marine Biology Institute, Shantou University, Shantou, Guangdong 515063, P.R. China \\ *Corresponding author
}

\section{A B S T R A C T}

Keywords

Microcystis

aeruginosa,

Nitrate; phosphate,

Chlorophyll-a, DPPH

radical-scavenging

activity, Superoxide

Dismutase activity.

Article Info

Accepted:

24 July 2016

Available Online:

10 August 2016
The fresh water microalgae Microcystis aeruginosa has been examined for its chlorophyll- $a$ and antioxidant enzymatic activities in different nitrate and phosphate concentrations. In the experiment, M. aeruginosa were cultured 28 days at $18^{\circ} \mathrm{C}, 25^{\circ} \mathrm{C}$ and $30^{\circ} \mathrm{C}$ in various light intensity. The maximum chlorophyll-a content was $33.79(\mathrm{mg} / \mathrm{L})$ in phosphate $(460 \mu \mathrm{M})$ at $30^{\circ} \mathrm{C}$. Superoxide dismutase (SOD) was significantly higher of $66.53 \%$ in phosphate $(980 \mu \mathrm{M})$ at $30^{\circ} \mathrm{C}$. DPPH radical scavenging activity of $78.16 \%$ in the nitrate $(329.5 \mu \mathrm{M})$ at $18^{\circ} \mathrm{C}$. The results showed that the maximum chlorophyll-a recorded at $30^{\circ} \mathrm{C}$ from $\mathrm{N}: \mathrm{P}, \mathrm{P}$ and $\mathrm{N}$ respectively. DPPH increased with nitrate concentration during the lower temperature and the SOD increased with phosphate in highest temperature. Chlorophyll- a content significantly compared with $18^{\circ} \mathrm{C}$ and $30^{\circ} \mathrm{C}(\mathrm{P}<0.05)$.

\section{Introduction}

Microcystis aeruginosa is a major primary producer and a common toxic cyanobacterium, playing an important role in the aquatic environment (Chen et al., 2016). Microcystis aeruginosa is commonly observed in highly eutrophic lakes (Watanabe and Oishi, 1985). In recent years, surface cyanobacterial bloom occurred frequently in most large shallow lakes in China, such as Lake Taihu (Zhang et al., 2009), Lake Dianchi (Shen et al., 2004) and Lake Chaohu (Liu, 2007), especially in summer, resulting from eutrophication caused by human activities. There are many studies on the factors that lead to water bloom and close relation between water bloom and concentration of nutrients, particularly phosphorus level was reported (Hecky and Kilham, 1988).Some researches indicated that the decline of cyanobacterial bloom was accompanied with the decrease in dissolved phosphorus (Chen et al., 2005).

Algae are generally abundant in eutrophic water bodies, in these aquatic environments it is commonly the case that high level nitrate and nitrite exist simultaneously, furthermore the concentration of nitrate usually is higher than nitrite (Okafor and Ogbonna, 2003 and Li et al., 2009). The chlorophyll a concentration in some lake 
areas was higher than $130 \mathrm{lg}$ L-1 (Kong et al., 2009). It is certain that toxic Microcystis blooms are harmful to human health in South China (Chen et al., 2009b). Super Oxide Dismutase (SOD) is a kind of active substance derived from the organisms, which can eliminate the harmful substances produced in the process of metabolism.

In many cyanobacteria, the greatest proportion of SOD activity in cells is due to Fe-SOD, whose concentration has been shown to increase when cyanobacteria are transferred from low to high levels of photosynthetically active radiation (Grilli Cailoa \& Canini, 1993). Therefore, the objective of this study was to determine the effect of $\mathrm{N}: \mathrm{P}$ concentrations in different temperatures, light intensity, Chlorophyll-a content and antioxidant enzyme response of Microcystis aeruginosa.

\section{Materials and Methods}

\section{Algal collection \& cultivation}

The fresh water cyanobacteria $M$. aeruginosa were isolated from Lotus lakeShantou, South China by micro-pipette methods and cultured in BG-11 medium (Rippka et al., 1979) with the modified N: P in five different concentrations; light: dark = $12 \mathrm{~h}: 12 \mathrm{~h} ; 850 \operatorname{lux}\left(18^{\circ} \mathrm{C}\right), 1600 \operatorname{lux}\left(25^{\circ} \mathrm{C}\right)$, and 2300 lux $\left(30^{\circ} \mathrm{C}\right)$. The species were identified using the light microscope and the stock cultures were maintained. All experiments were carried out in triplicate, totally forty five conical flask $(250 \mathrm{ml})$ were used.

The effect of $\mathrm{NaNO}_{3}$ and $\mathrm{K}_{2} \mathrm{HPO}_{4}(\mu \mathrm{M} / \mathrm{ml})$ composition was variable, In nitrate $117.7 \mu \mathrm{M}, 175 \mu \mathrm{M}, 235 \mu \mathrm{M}, 282.4 \mu \mathrm{M}$ and $329.5 \mu \mathrm{M}$; phosphate $110 \mu \mathrm{M}, 230 \mu \mathrm{M}$, $460 \mu \mathrm{M}, \quad 750 \mu \mathrm{M}$ and $980 \mu \mathrm{M} ; \quad \mathrm{N}: \mathrm{P}$ propositions $117.7-110 \mu \mathrm{M}, \quad 175-230 \mu \mathrm{M}$, $235-460 \mu \mathrm{M}, \quad 282.4-750 \mu \mathrm{M}$ and 329.5$980 \mu \mathrm{M}$.

\section{Preparation of enzyme extracts}

Antioxidant enzyme activity assays was performed with biomass obtained from 10 $\mathrm{mL}$ of Microcystis aeruginosa culture, by homogenizing in $0.1 \mathrm{M}$ phosphate buffer $(\mathrm{pH} \quad 6.5) \quad$ containing $\quad 1 \% \quad(\mathrm{w} / \mathrm{v})$ polyvinylpyrrolidone (PVP), and centrifuging the homogenate at $10,000 \times \mathrm{g}$ and $0^{\circ} \mathrm{C}$ for $10 \mathrm{~min}$. The supernatant was used for total proteins measurement and antioxidant enzyme activity assays (Mathias Ahii Chia et al., 2015).

\section{Chlorophyll 'a'}

$5 \mathrm{ml}$ of M.aeruginosa biomass was concentrated and centrifugation (4000rpm) of $8 \mathrm{ml}$ culture at ambient temperature for 5 min. The supernatant was discarded and the pellet was re-suspended and macerated in 5 $\mathrm{ml}$ of $90 \%$ acetone and kept it 14 hours incubation. Again centrifuged $10 \mathrm{~min}$ and the absorbance of the supernatant were measured at $750 \mathrm{~nm}, 664 \mathrm{~nm}, 647 \mathrm{~nm}, 630 \mathrm{~nm}$ (GB 17378.7, 2007).

\section{DPPH radical-scavenging activity}

The scavenging effects of samples for DPPH radical were monitored according to the method of Yen and Chen, 1995. Briefly, a $2.0 \mathrm{ml}$ of aliquot of test sample was added to $2.0 \mathrm{ml}$ of $0.16 \mathrm{mM}$ DPPH methonolic solution. The mixture was vortexed for 1 min in the dark, and its absorbance was read at $517 \mathrm{~nm}$. The ability to scavenge the DPPH radical was calculated using the formulae given by Duan et al., 2006. Synthetic antioxidants, Gallic acid and ascorbic acid were used as positive controls. 


\section{Superoxide Dismutase activity}

SOD activity was assayed according to the method of Beauchamp and Fridovich (1971). The reaction mixture contained 0.8 $\mathrm{mL}$ PBS solution $(50 \mathrm{mM}, \mathrm{pH} 7.8), 0.3 \mathrm{~mL}$ methionine solution $(130 \mathrm{mM}), 0.3 \mathrm{~mL}$ Na2EDTA solution $\left(\begin{array}{llll}100 & 1 \mathrm{M}\end{array}\right), \quad 0.3 \mathrm{~mL}$ riboflavin solution $(20 \mathrm{lM}), 0.3 \mathrm{~mL}$ nitroblue tetrazolium (NBT) solution (750 lM), and 1 $\mathrm{mL}$ enzyme extract for a total volume of 3 $\mathrm{mL}$. As SOD has the ability to inhibit the photochemical reduction of NBT, this assay utilized negative controls (silver paper wrapped around the test tube to mimic fully dark condition without any photochemical reduction of NBT), positive controls (deficiency of SOD activity in light with full photochemical reduction of NBT), and treatment groups (in light with SOD inhibition on photochemical reduction of NBT). The absorbencies of all experimental tubes were measured at $560 \mathrm{~nm}$ after a 20 min irradiance of $40-60 \mathrm{mmol}$ photons $\mathrm{m}^{-2}$ $\mathrm{s}^{-1}$. One unit of SOD activity was defined as the amount of enzyme that inhibited 50\% of photochemical reduction of NBT.

\section{Statistical analysis}

All experiments were performed in three replicates. Prism5 Statistical software was applied to analyze the data. A T-test was used to examine whether there is difference in temperature of chlorophyll $-a$. Differences were considered to be significant at $\mathrm{P}<$ 0.05 .

\section{Results and Discussion}

\section{Estimation of Chlorophyll - $a$}

Chl-a concentration of $M$. aeruginosa significantly showed at $30^{\circ} \mathrm{C}$ higher than that at $25^{\circ} \mathrm{C}$ and $18^{\circ} \mathrm{C}$. In phosphate concentration, the Chl-a $(460 \mu \mathrm{M})$ showed $33.79(\mathrm{mg} / \mathrm{L})$ at $30^{\circ} \mathrm{C}$ followed by nitrate $22.95(\mathrm{mg} / \mathrm{L})$ at $30^{\circ} \mathrm{C}(117.7 \mu \mathrm{M})$ and nitrate-phosphate $19.71(\mathrm{mg} / \mathrm{L})$ at $30^{\circ} \mathrm{C}(235$ $460 \mu \mathrm{M}$ ) were recorded (Fig1).

\section{DPPH radical scavenging activity}

DPPH radical scavenging activities (\%) of M.aeruginosa showed significantly higher activity of $78.16 \%$ in the nitrate at $18^{\circ} \mathrm{C}$ $(329.5 \mu \mathrm{M})$ and $25^{\circ} \mathrm{C} \quad(329.5-980 \mu \mathrm{M})$ followed by nitrate-phosphate $66.75 \%$ at $30^{\circ} \mathrm{C}(117.7-110 \mu \mathrm{M})$, phosphate $62.23 \%$ at $30^{\circ} \mathrm{C}(750 \mu \mathrm{M})$ and $57.69 \%$ in $30^{\circ} \mathrm{C}(230$ $\mu \mathrm{M})$ (Fig 2).

Fig.1 Effect of nitrate-phosphate, nitrate and phosphate on Chlorophyll-a of M. aeruginosa
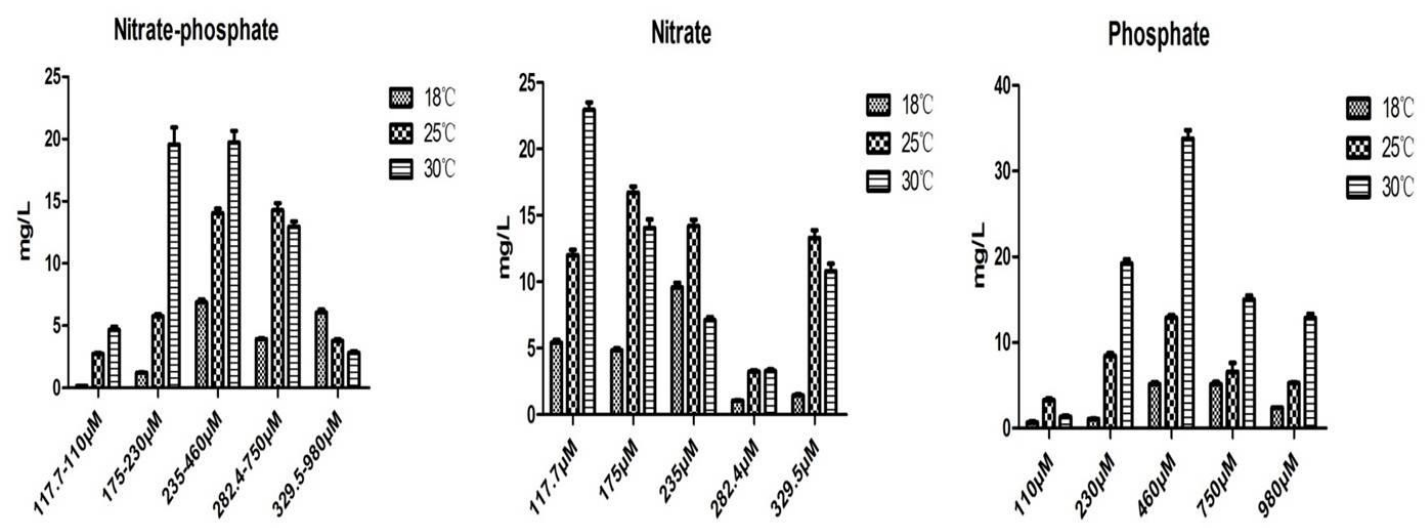
Fig.2 Effect of nitrate-phosphate, nitrate and phosphate on DPPH radical scavenging assay of $M$. aeruginosa
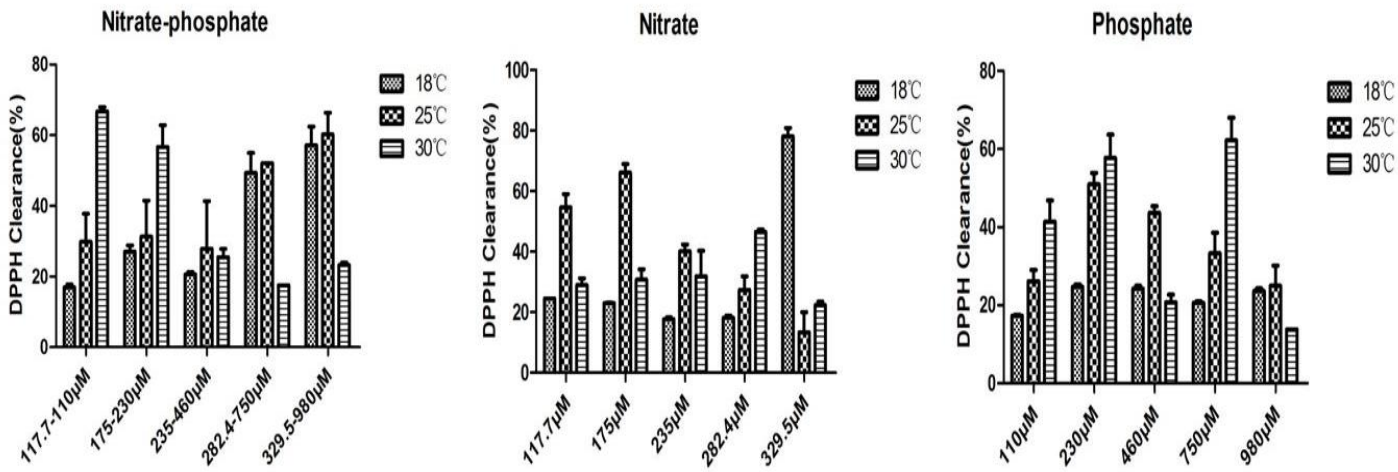

Fig.3 Effect of nitrate-phosphate, nitrate and phosphate on SOD activity of M. aeruginosa cell
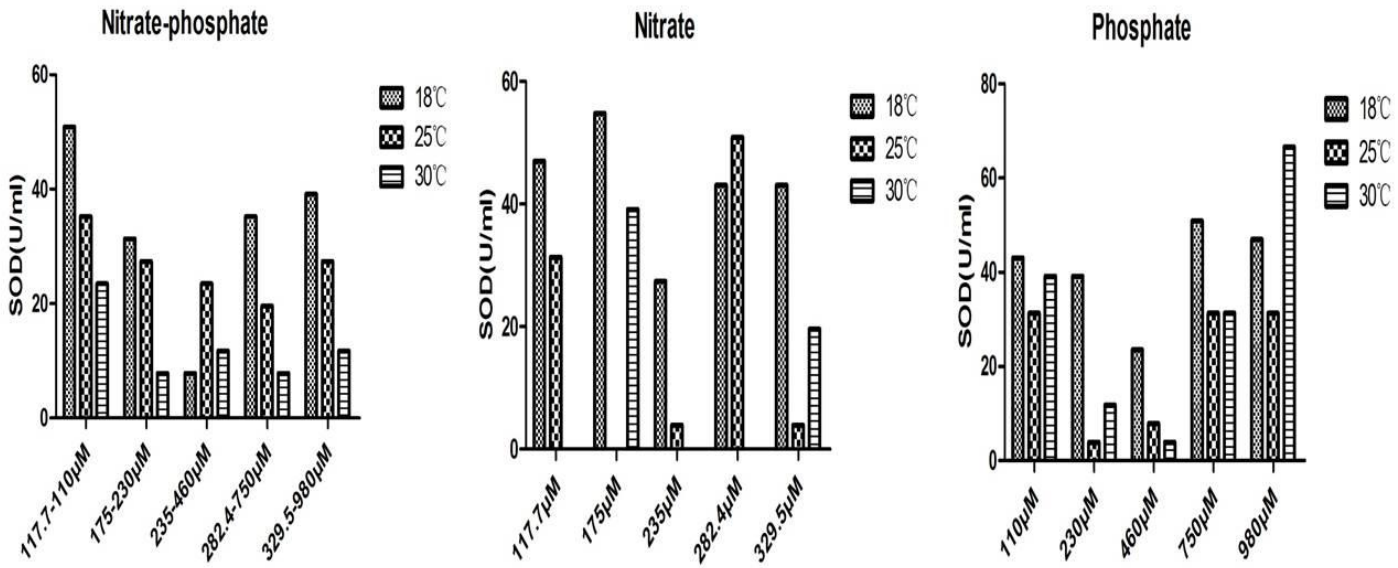

\section{Superoxide Dismutase activity}

SOD activity of M.aeruginosa increasing by 50.87 to $66.53 \%$ and showed significantly higher activity $66.53 \%$ in phosphate at $30^{\circ} \mathrm{C}$ $(980 \mu \mathrm{M})$ followed by $54.79 \%$ at $18^{\circ} \mathrm{C}(175$ $\mu \mathrm{M}), 50.87 \%$ in nitrate-phosphate at $18^{\circ} \mathrm{C}$ $(117.7-110 \mu \mathrm{M})$ and $50.87 \%$ in nitrate at $25^{\circ} \mathrm{C}(282.4 \mu \mathrm{M})$ were recorded (Fig 3).

M. aeruginosa is a prokaryotic cyanobacterium. The chlorophyll -a content significantly decreased with increased concentrations of nitrate-phosphate. These results are consistent with those of $\mathrm{Hu}$ et al., (2012), who studied the effect of berberine sulphate on chlorophyll -a levels in $M$. aeruginosa cells. The Chl-a concentration Increased during the high temperature. This result was similar to the result of Burke, who found that a $38^{\circ} \mathrm{C}$ pre- incubation temperature provided maximum chlorophyll accumulation following the high temperature exposure (Burke, 2001). Adaptation of $M$. aeruginosa for high temperature is also associated with upregulation of protective enzymes because protective enzymes can defend against free radicals (Xu et al., 2006). The levels of SOD and DPPH in the $M$. aeruginosa were used in our study varied to different concentrations of nutrients (NP; $\mathrm{P}$ and $\mathrm{N})$. 
SOD activity increased in response to high concentrations of NPs (Jingxian Wang, 2007). Similarly, SOD activity increased in high concentrations of nitrate and phosphates with the temperatures at $30^{\circ} \mathrm{C}$ and $25^{\circ} \mathrm{C}$. In the laboratory culture the high concentrations of nitrate and phosphate (25$30^{\circ} \mathrm{C}$ ) showed the moderate values of SOD, whereas the maximum values of SOD was $18^{\circ} \mathrm{C}$ with the low level of nitrate-phosphate concentration. Overall, present investigation indicating that Microcystis aeruginosa has a strong ability to adapt to variations in environmental conditions. In conclusion, the results of this study show that DPPH and SOD enzymes are present in the bloomproducing species $M$. aeruginosa.

\section{Acknowledgements}

This work was supported by International Cooperation Project of Guangdong Science \& Technology Department (2011B050 300026); Guangdong Provincial Scientific \& Technological Project (2012B020308007); Guangdong High-Level University Project "Green Technologies for Marine Industries" (No. 130-33106703); Guangdong Natural Science Foundation (2016A030313065).

\section{References}

Beauchamp, C. and Fridovich, I. 1971. Superoxide Dismutase: Improved Assays and an Assay Applicable to Acrylamide Gels. Anal. Biochem., 44: 276-287.

Burke, J.J. 2001. Identification of genetic diversity and mutations in higher plant acquired thermo tolerance. Physiol. Plantarum, 112: 167-170.

Chen, L., Gin, K.Y.H., He, Y. 2016. Effects of sulfate on microcystin production, photosynthesis, and oxidative stress in Microcystis aeruginosa. Environ. Sci. Pollut. Res. Int., 23(4): 3586-95.
Chen, Y., Tang, L., Chen, L., Li, J. 2005. Spatial and temporal variations of phosphorus in Dianchi Lake. J. AgroEnviron. Sci., 24: 1145-1151 (in Chinese with English abstract).

Duan, X.J., Zhang, W.W., Li, X.M., Wang, B.G. 2006. Evaluation of Antioxidant property of extract and fractions obtained from a red alga, Polysiphonia urceolata. Food Chem., 95: 37-43.

Grilli Caiola, M., Canini, A. 1993. Immunocytochemical localization of Fe-SOD in different cells of Anabaena cylindrica Lemm. grown at two different photon irradiances. New Phytologist, 125: 361-366.

Hecky, R.E., Kilham, P. 1988. Nutrient limitation of phytoplankton in freshwater and marine environments: a review of recent evidence on the effects of enrichment. Limnol. Oceanogr., 33: 796-822.

Hu, Y.J. and H.W. Ni. 2012. Bioactivity evaluation of Berberine Sulfate on Microcystis aeruginosa. Agrochemical, 51(5): 382-384.

Jingxian Wang, Ping Xie. 2007. Antioxidant enzyme activities of Microcystis aeruginosa in response to nonylphenols and degradation of nonylphenols by Microcystis aeruginosa. Environ. Geochem. Health, 29: 375.

Liu, W. 2007. Water quality analysis in Lake Chaohu when a cyanobacterial bloom occurred. Environ. Monitor. China, 23: 101-102 (in Chinese with English abstract).

Oyaizu, M. 1986. J. Nutri., 44: 307-315.

Mathias Ahii Chia, Micheline Kezia Cordeiro-Araujo, Maria do Carmo Bittencourt-Oliveira. 2015. Growth and antioxidant response of Microcystis aeruginosa (Cyanobacteria) exposed to anatoxina. Harmful Algae, (49): 135-146. 
Okafor, P.N., U.I. Ogbonna. 2003. Nitrate and nitrite contamination of water sources and fruit juices marketed in south-eastern Nigeria. J. Food Composition and Analysis, 16(2): pp. 213-218.

Rippka, R., J. Deruelles, J.B. Waterbury, M. Herdman, R.Y. Stanier. 1979. Generic assignments, strain histories and properties of pure cultures of cyanobacteria, J. Gen. Microbiol., 111: 1-61.

Shen, Y., Liu, Y., Wu, G., Ao, H., Qiu, C., 2004. Mechanical removal of heavy cyanobacterial bloom in the hypereutrophic Lake Dianchi. Acta Hydrobiol., Sin. 28: 131-136 (in Chinese with English abstract).

Singleton, V.L., Rossi, J.A. 1965. Colorimetry of total phenolics with phosphomolybdic-phosphotungstic acid reagents, 1965. American J. Enol. Viticulture, 16: 144-153.

The State Standard of the People's Republic of China. 2007. GB 17378.7-2007. The Determination of Chlorophyll- $a$.

Watanabe, M.F. \& Oishi, S,1985. Effects of environmental factors on toxicity of a cyanobacterium

(Microcystis aeruginosa) under culture conditions. Appl. Environ. Microbiol., 49: 1342 1344.

Xu, S., Li, J., Zhang, X., Wei, H., Cui, L. 2006. Effects of heat acclimation pretreatment on changes of membrane lipid peroxidation, antioxidant metabolites, and ultrastructure of chloroplasts in two cool-season turf grass species under heat stress. Environ. Exp. Bot., 56: 274-285.

Li, Y.F., W.F. Wan, J. Song. 2009. Classification of groundwater contamination in Yuxi river valley, Shaanxi Province, China. Bull. Environ. Contamination and Toxicol., 82: pp.234-238.

Yen, G.C., Chen, H.Y. 1995. Antioxidant activity of various tea extracts in relation to their antimutagenicity. $J$ Agri. Food Chem., 43: 27-37.

Zhang, N., Li, G., Yu, J., Ding, M., Xu, L. 2009. Characteristics of cyanobacterial blooms occurred in Lake Taihu. Environ. Monit. China, 25: 71-74 (in Chinese with English abstract).

\section{How to cite this article:}

Yanfei Li, Ping Li, Peihang Xu, Yinglin Wu, Wenhua Liu and C. Santhoshkumar. 2016. Effect of Nutrients and Antioxidant Enzyme Activities from Microcystis aeruginosa. Int.J.Curr.Microbiol.App.Sci. 5(8): 571-576. doi: http://dx.doi.org/10.20546/ijcmas.2016.508.063 